

THE GEOLOGICAL SOCIETY OF AMERICA

\title{
Predicting Rock Mass Decay in Engineering Lifetimes: The Influence of Slope Aspect and Climate
}

\author{
MARCO HUISMAN
}

Bluewater Energy Services, P.O. Box 3102, 2130KC Hoofddorp, The Netherlands

HENRI ROBERT GEORGE KENNETH HACK

International Institute for Geo-Information Science and Earth Observation, P.O. Box 6, 7500AA, Enschede, The Netherlands

JAN DIRK NIEUWENHUIS

Faculty of Civil Engineering and Geosciences, Delft University of Technology, Stevinweg 1, 2628 CN Delft, The Netherlands

Key Terms: Slope Stability, Weathering, Weathering Rate, Slope Design, Prediction, Climate

\begin{abstract}
Following the initial stress release after excavation of a road cut, weathering and erosion processes will start acting on the newly exposed slope material. As field observations show, the resulting degradation may have significant effects well before the envisaged engineering lifetime of the slope ends. The data set obtained by 12 years of fieldwork by the International Institute for Geo-Information Science and Earth Observation and Delft University of Technology was used to assess and quantify the time-related degradation of rock masses by weathering. The results of a bootstrap analysis of the data show a close relationship between the weathering rates, the slope aspect, and the prevailing wind directions during rainfall events. For the study area around Falset it can be concluded that in shales, marls, and similar materials containing clays (especially swelling clays), weathering rates are highest in slopes facing the prevailing winds during rainfall because of more frequent and intense cyclic wetting and drying. The same holds true for more resistant materials such as limestones, which are interbedded with weak materials such as shales and marls. In soluble materials such as the gypsum unit investigated here, water retention in slopes sheltered from the winds facilitates chemical weathering, and it is in these lee-side slopes that the highest weathering rates are found. These relations can be used to predict weathering rates and, therefore, also weathering degree as a function of
\end{abstract}

time. With the use of a probabilistic slope-stability assessment method, the time-related slope stability can also be predicted.

\section{INTRODUCTION}

This research article deals with the investigation and determination of temporal aspects in soil and rock mass movement and their relation to the degradation of geotechnical characteristics of soil and rock mass in time. For the safe construction of a structure with respect to its envisaged engineering lifetime, it is of vital importance to incorporate three items in the initial design: the presentday geotechnical characteristics, the dominant timerelated processes that control the engineering behavior of soil and rock masses, and the rate of deterioration of the geotechnical properties (Fookes et al., 1988). This time-related degradation of soil and rock affects all engineering structures that involve natural, in situ materials, but is most easily recognized in man-made slopes on which the study at hand focuses.

\section{STUDY AREA}

The data used for this research was collected in an area surrounding the town of Falset, in the Tarragona province in northeastern Spain (Figure 1). Here, the southwestnortheast orientated El Camp mountains separate the coastal plains to the southwest of Reus, from the Ebro river basin around Mora d'Ebre. The El Camp range rises up to about 1,000 m above sea level; the town of Falset itself lies on the western side of the range at an altitude of $350 \mathrm{~m}$ asl.

The Catalan Coastal Ranges, of which the El Camp is 




Figure 1. The study area around the town of Falset, Catalunya, northeastern Spain.

part, form a system of ridges and depressions parallel to the Catalan coast trending from the southwest to the northeast, with the highest point approximately 1,700 m above sea level in the southeastern edge of the Ebro Basin (Masana, 1994).

According to Masana (1994), the ranges and depressions are the emerged sector of the northwestern edge of the Catalan-Valencian domain of the Valencia trough, "The structure is characterized by an echelon fault system, subparallel to the coast, that affected the Hercynian basement and the Mesozoic overlying sediments. These basement faults had strike and reverse slip component during the Paleocene and acted later as normal faults to accommodate the extension that took place from the Late Oligocene to the present. The Neogene extension in the Valencia trough was intense during the early Miocene and decreased during middle and upper Miocene and in the Pliocene. In the latest periods the deformation was concentrated mainly in the edges of the trough and concentrated in the major marginal faults. The normal faults have created a 'horst and graben' system with Miocene to Quaternary basin infilling. From SW to NE the basins studied in the area are el Baix Ebre, el Camp and Vallès-Penedès" (Masana, 1994).

The stratigraphy of the study area consists of a sedimentary rock sequence of Devonian through to Quaternary age. Pre-Mesozoic igneous rocks occur, intruded into Carboniferous formations as granodiorite bodies and aplitic dykes and possibly associated with the
Hercynian orogeny. Additional minor intrusive phases occurred during the Alpine orogeny. The data used in this study were collected in the Triassic formations of the Middle Muschelkalk, Upper Muschelkalk, and Keuper, which correspond to the Germanic facies (Krömmelbein, 1976). These Germanic facies types of the formations deposited in the Triassic, from the Buntsandstein up to the Keuper, have received a good deal of attention in the literature (e.g., López-Gómez et al., 1993; Morad et al., 1995; Vecsei, 1998; and Vescsei and Mandau, 2002).

This Triassic sequence is characterized by massive or very thick bedded sandstones with some conglomerate beds at the base (Buntsandstein), followed by thick bedded limestones and dolomites (Lower Muschelkalk), partly deformed sandy clayey siltstone with gypsum (Middle Muschelkalk), limestones and dolomites with marly intercalations (Upper Muschelkalk), and a series of shales and siltstones, in the lower part interbedded with limestones and dolomites (Keuper). On top of the Keuper, as the youngest formation in the Triassic, undifferentiated dolomites occur. Data for the research described in this article were gathered for the Middle Muschelkalk up to the Keuper; descriptions of these rocks are given in Table 1. The stratigraphy, tectonic development, structural geology, and formations distinguished in the area are described in the geologic maps by the Instituto Geologico y Minero de España (see the IGME reference).

The climate in the area is characterized by dry, hot summers (temperatures range from $15^{\circ} \mathrm{C}-35^{\circ} \mathrm{C}$ ), and 
Predicting Rock Mass Decay in Engineering Lifetimes

Table 1. Description of studied rock units.

\begin{tabular}{|c|c|c|}
\hline Formation & Unit & $\begin{array}{c}\text { Description } \\
\text { (BS5930, 1981) }\end{array}$ \\
\hline \multirow[t]{2}{*}{ Keuper } & Limestones & $\begin{array}{l}20-100 \mathrm{~cm} \text { thick off-white/light } \\
\text { grey, argillaceous to fine } \\
\text { arenaceous LIMESTONE } \\
\text { and DOLOMITE. }\end{array}$ \\
\hline & Shales & $\begin{array}{c}\text { Red/green/greenish blue/brown/ } \\
\text { yellow/off-white, argillaceous } \\
\text { to fine arenaceous, calcareous } \\
\text { sandy silty SHALES, with } \\
\text { (small) quantities of gypsum. }\end{array}$ \\
\hline $\begin{array}{l}\text { Upper } \\
\quad \text { Muschelkalk }\end{array}$ & $\begin{array}{l}\text { Bedding spacing } \\
>0.50 \mathrm{~m} \\
\text { Bedding spacing } \\
0.10-0.50 \mathrm{~m} \\
\text { Bedding spacing } \\
\quad<0.10 \mathrm{~m}\end{array}$ & $\begin{array}{l}\text { Off-white/light grey/yellowish } \\
\text { grey, argillaceous to fine } \\
\text { arenaceous LIMESTONE } \\
\text { and DOLOMITE } \\
\text { (differentiated based on } \\
\text { bedding spacing). }\end{array}$ \\
\hline $\begin{array}{l}\text { Middle } \\
\quad \text { Muschelkalk }\end{array}$ & $\begin{array}{l}\text { Siltstones } \\
\quad \text { (gypsum } \\
<50 \%) \\
\text { Gypsum } \\
\quad \text { (gypsum } \\
\quad>50 \% \text { ) }\end{array}$ & $\begin{array}{l}\text { Red (occasionally greenish } \\
\text { grey), argillaceous to fine } \\
\text { arenaceous, gypsiferous } \\
\text { clayey sandy SILTSTONE; } \\
\text { large quantities of gypsum } \\
\text { up to occasionally } 80 \% \\
\text { (differentiated based on } \\
\text { gypsum content). }\end{array}$ \\
\hline
\end{tabular}

moderate winters (with average daytime temperatures of $10^{\circ} \mathrm{C}-15^{\circ} \mathrm{C}$ ), in which temperatures may reach below $0^{\circ} \mathrm{C}$ in the mountains. Rivers and streams in the area are mostly dry from March until October or November. It may rain for long periods during the winter, sometimes torrentially, and the rain may last until March or April, although this is not typical. The topography of the area, in combination with the prevailing wind directions, leads to the formation of several microclimates and, in broad terms, three sub-areas can be distinguished on the basis of the local climate. An overview of average climate data is given in Table 2.

Extensive agricultural use is made of the soft soils and weathered rocks in the valleys and the coastal plain. The more mountainous areas that consist of stronger rock masses are partly barren, but mainly covered with shrubbery and forests (mainly pine). A number of small settlements are found near the fertile areas and are connected by a system of roads and tracks. Many road cuts in the area have been constructed or renewed in the first half of the twentieth century using several excavation techniques. In the period since 1988, new roads have been constructed and some of the older roads have been realigned. Especially for the recent constructions, detailed age information is available (e.g., Huisman, 2001). Slopes dating from both these construction periods have been classified by students and staff in the course of engineering geologic fieldwork by the International Institute for GeoInformation Science and Earth Observation in cooperation with the Delft University of Technology.
Table 2. Climatic data for the Falset area (Generalitat de Catalunya, Departament de Medi Ambient).

\begin{tabular}{llll}
\hline \hline & Ebro Basin & El Camp Front & Coastal Plains \\
\hline $\begin{array}{c}\text { Mean annual } \\
\text { temperature }\left({ }^{\circ} \mathrm{C}\right)\end{array}$ & 14 to 16 & 12 to 14 & 15 to 17 \\
$\begin{array}{c}\text { Mean annual } \\
\text { precipitation } \\
(\mathrm{mm})\end{array}$ & 400 to 550 & 600 to 750 & 500 to 650 \\
$\begin{array}{c}\text { Mean annual } \\
\text { evapotranspiration } \\
\text { (mm) }\end{array}$ & 700 to 1,000 & 600 to 850 & 700 to 850 \\
$\begin{array}{c}\text { Mean Thornthwaite } \\
\text { climate index (mm) }\end{array}$ & -40 to -20 & -20 to +20 & -40 to 0 \\
\hline
\end{tabular}

\section{CLASSIFICATION METHOD}

The basis for the degradation analysis of the slopes in this study is the Slope Stability Probability Classification (SSPC) system, which was validated specifically for the research area (Hack, 1998). The classification involves a description of the rock material and rock mass properties such as grain size, color, mass structure, and block size strength according to the British Standard BS5930 (1981), together with a more elaborate description of the discontinuities. The SSPC method can be described as a three-step classification system and considers three rock masses (Hack et al., 2003; see also Figure 2):

1. The rock mass in the exposure (i.e., exposure rock mass)

2. The rock mass in an unweathered and undisturbed condition before excavation (i.e., reference rock mass)

3. The rock mass in which the existing or new slope is to be situated (i.e., slope rock mass)

The classification and slope-stability prediction methodology is discussed by Hack and others (2003). In the SSPC, the stability of a (future) slope in the slope rock mass is determined in two different analyses: orientation dependent or orientation independent. The first is related to the orientation of the discontinuities and the slope and considers sliding and toppling, and the second considers slope failure that is not related to discontinuities.

Because the slope rock mass strength properties and the resulting slope stability as found with the SSPC system directly depend on the degree of weathering in the slope rock mass, this parameter has to be predicted when the stability is to be assessed for some time in the future. A first approximation can be found from a plot of the recorded degrees of weathering in different slopes cut into the same engineering geologic units that are subjected to similar weathering conditions against their different exposure times (de Jong, 2003).

The degree of weathering is quantified in the SSPC system with the coefficients WE (for the exposure 


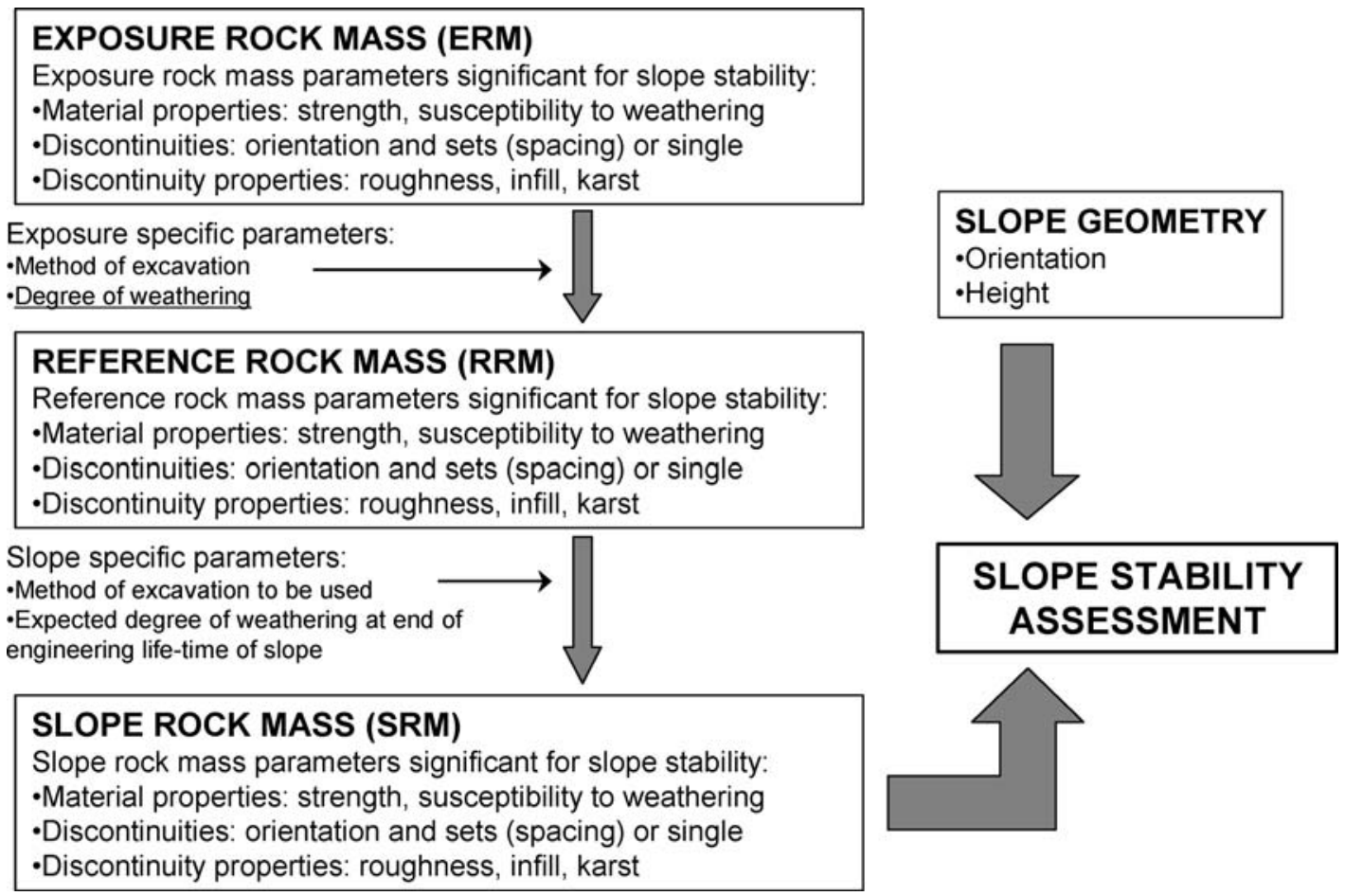

Figure 2. Schematic methodology of the SSPC system.

rock mass) and SWE (for the slope rock mass); WE and SWE are values less than or equal to one, representing the decrease in strength properties by weathering. The coefficient is assigned to the different weathering degrees of the British Standard BS5930 (1981) according to Table 3 (Hack and Price, 1997); unweathered rock has a WE equal to 1.00 , which indicates the full mass strength.

Generally, the intensity of weathering will change in depth, with a weathering front penetrating into the rock mass exposed in a slope. Therefore, we can expect to find the weathering degree to be gradually decreasing with depth. The question of which WE to assign to the rock mass does then not only depend on the intensity of weathering itself, but also on what penetration depth of a particular weathering degree is of engineering significance with respect to slope stability. This should be well considered when making such classifications.

This implies that, ideally, the weathering degree that

Table 3. WE values for different weathering degrees (validated for the study area).

\begin{tabular}{lc}
\hline \hline Degree of Weathering in Slope & WE (SSPC) \\
\hline Unweathered & 1.00 \\
Slightly weathered & 0.95 \\
Moderately weathered & 0.90 \\
Highly weathered & 0.62 \\
Completely weathered & 0.35 \\
\hline
\end{tabular}

should be assigned to (a unit in) a rock mass exposed in a slope decreases simultaneously with the decrease in engineering strength properties that play a role in slope stability. In reality, this is not the case because the weathering degree can only be described as one out of a limited number of options (see Table 3). Therefore, even when the classification perfectly describes the engineering-wise appropriate weathering degree, the outcome will be a discontinuous transition from one weathering degree to another at a specific time rather than a continuous process. If some uncertainty resulting from personal bias or intrinsic variability plays a role, this discontinuous character of the development may actually be less pronounced and fuzzier. Furthermore, erratic interruptions of the process (e.g., sudden erosion events such as falling blocks) will also disrupt the ideal picture.

\section{ROCK MASS WEATHERING}

In an engineering geologic context, Price (1995) defined weathering as "the irreversible response of soil and rock materials and masses to their natural or artificial exposure to the near-surface geomorphologic or engineering environment." Parameters controlling weathering in artificial slopes fall in three categories:

1. Internal: rock and soil material and mass properties such as permeability, discontinuities, and material composition 
2. External: parameters related to the weathering environment such as climate, topography, and vegetation

3. Geotechnical: parameters related to slope design such as aspect, slope angle, height, method of excavation, and drainage measures

Both the internal and external parameters are functions of time and may have considerably changed from conditions in the past during the history of the site. To some extent, geotechnical parameters like slope geometry are possibly changing in the course of time too (e.g., if the profile of an existing slope is modified).

A rock and soil material or mass will show a certain response to the particular combination of weatheringcontrolling parameters at the site of its exposure, and the intensity and rate of this response is the susceptibility to weathering as described by Hack (1998), as the "susceptibility of a rock mass to further weathering in the future." This is a concept that is frequently addressed by some constant coefficient, which is commonly called the weathering rate of a rock material or mass. However, the use of a constant weathering rate as is common in the literature on this subject (e.g., Matsukura and Hirose, 1999; Inkpen and Jackson, 2000; Williams and Robinson, 2000; and Trudgill et al., 2001), usually defined in terms of material loss per area per unit time, implies that the rate at which weathering processes occur is constant with respect to time. Physically, this seems unlikely. When degradation is regarded as the reaction of a rock mass to a disequilibrium in its state and the prevailing internal, external, and geotechnical conditions, it seems likely that the weathering rate is related to the magnitude of the driving forces of degradation and, therefore, the degree of disequilibrium. In other words, weathering rates may be expected to decrease with time as the state of the rock mass becomes more and more in equilibrium with its surroundings. This was indeed found in such experimental weathering studies as reported by Colman (1981) and during field tests such as those performed by White and Brantley (2003). In Kühnel and others (1994), corresponding theoretical results are described.

The question of how to define weathering-intensity rates, and by doing so how to quantify susceptibility to weathering, primarily depends on how the intensity of weathering at a specific moment in time can actually be quantified. The change of this intensity per unit time is then in its most strict definition the weathering intensity rate but, as previously discussed, it is preferred to define a variable describing the susceptibility to weathering in such a way that it only depends on the existing set of weathering parameters and not on time itself. Such a variable could not only be used to quantify the rate of the decay process active in a slope at one particular moment in time, but also to extrapolate the present-day situation into the future, thus predicting the weakening of a rock or soil mass and, ultimately, the resulting decrease of slope stability within the planned engineering lifetime of a slope.

A common method to quantify weathering is to use a ratio of sound and unsound constituents. One example of this is found in Irfan and Dearman (1978), who expressed a micropetrographic index for a weathered Cornwall granite as the ratio of sound and unsound constituents. Other researchers such as Ruxton (1968, cited by Colman, 1981) have used largely similar parameters to define the decay of materials rather than masses. Although such an approach indeed gives an objective measure for the intensity of weathering, or at least the changes brought about in the original materials, it has the disadvantage of being totally dependent on the decay process. Results for a different parent material, a different weathering environment, and such cannot be compared and, in that respect, it is a very specific parameter that is a good quantitative measure for one specific combination of materials and weathering environment, but a poor qualitative measure to compare different materials or different environments (and, therefore, sites). Furthermore, its use is limited to cases in which chemical weathering prevails over mechanical weathering (or where mechanical weathering is absent), so that a change in material composition indeed is an indicator of the overall weathering process. In geo-engineering, any study into rock-mass decay in time for use in slope stability issues will commonly have to address different sites, settings, weathering processes, materials, and masses and, therefore, the use of such specific parameters as mineral indices is limited.

A detailed overview of possibilities to assess weathering intensities by (index) testing is given by Martin (1986). This usually takes the form of a strength estimate by simple means (e.g., using hands, pocket knives, and geologic hammers) or by more complicated devices (e.g., using Schmidt hammers or seismic equipment). It should be noted that however useful a strength estimate might be for engineering purposes, it does not necessarily relate to the intensity of weathering because that parameter relates to a change in properties from some parent material rather than some absolute value of that property. To give an example in absolute terms, a moderately weathered granite is likely to be stronger both as a material and as a mass than a slightly weathered shale. This difference between the intensity of weathering and the geotechnic consequences of weathering should be made and cannot be made clearly enough. A further complexity in this respect is that weathering may actually lead to a (local) increase of strength such as by case hardening (e.g., Winkler, 1997; Bland and Rolls, 1998). It should also be considered that a slope in a highly weathered rock mass that behaves as geotechnic soil may show a different failure mode (e.g., rotational) than that same rock mass 
in a less weathered state (e.g., sliding, toppling), with different stability indices.

The slake durability test, which is often used to quantify slaking properties of mudrocks, also falls into this category. Generally, the results of such index tests are useful to predict the performance of different rock types in a qualitative manner, but they often cannot be used to predict the quantitative behavior of the rocks tested under field conditions [although correlations between slake durability and field performance do exist, such as published by Dick and Shakoor (1995) and Shakoor (1995)]. Hack (1998), Hack and Huisman (2002), and Nicholson (2001) have demonstrated that material tests have severe limitations in predicting mass performance, especially when discontinuities influence the mass behavior. This should be noted when applying index testing.

Because of the considerations with respect to chemical indices and index testing, classification systems are still often preferred for quantifying the general quality of a rock mass and its weathering degree. In such classification systems, the intensity of weathering is usually quantified using standardized "classes" or "degrees" of weathering. A well-known example is the British Standard classification of BS5930 (1981, 1999; see also Dearman, 1995). An alternative would be a rating system such as proposed by Laubscher (1990) and Price (1993); these are, however, not yet standardized.

In the SSPC classification system used in this study (Hack, 1998), the degree of weathering is quantified with the parameters WE (for the exposure rock mass) and SWE (for the slope rock mass) as mentioned earlier. The parameter is assigned to the different weathering degrees of the British Standard BS5930 (1981) according to Table 3. It is important to note that WE is not "just" a measure for the weathering degree on the actual surface of the slope; it is, in fact, representing the rock mass determining slope stability and is, therefore, assigned in accordance with the weathering degree that is of engineering significance with respect to slope stability. The parameter $\mathrm{WE}_{\text {init }}-\mathrm{WE}_{t}$ (where $\mathrm{WE}_{\text {init }}$ is the initial degree of weathering and $\mathrm{WE}_{t}$ is the degree of weathering at some time $t$ ) is then a measure for the change in weathering.

With the subdivision of weathering intensity into classes, one touches on the subject of the limited objectivity of the observations on which the classification is based. This is a complex problem in itself. One not only has to deal with the personal interpretation by the observer of the specific combination of properties that a material or mass should have to fall within a class according to the standards, but also by how observers actually perceive slopes. An observer generally does not base his or her judgment of slopes on the twodimensional surface of the exposed rock, but rather bases its description on the uppermost "skin" of the rock mass. This three-dimensional volume would be in the order of millimeters in most limestones and dolomites and in the order of centimeters in the case of weak rock formations (that commonly have a much more irregular surface). Therefore, the classification is inevitably some sort of average over the conditions found in that weathered uppermost layer. The extent of this zone on which an observation is based would usually decrease in more competent materials with less mechanical decay. It should be noted that it is not necessarily the same as the depth over which weathering has penetrated the rock or soil mass.

Keeping all these considerations in mind, the results of weathering classifications done using the SSPC can, thus, be used to verify this notion of weathering rates that decrease in time. For road cuts of a certain age, we know the current value for WE (refer to Table 3) and, in many cases, we can estimate the initial WE at the time of excavation. The decrease in WE that has occurred during the elapsed time of exposure can be plotted against the slope age. This has been done for three formations in the study area, encompassing seven different geotechnic units (Middle Muschelkalk siltstones and gypsum; Upper Muschelkalk with bedding spacing $0.0 \mathrm{~m}-0.1 \mathrm{~m}, 0.1 \mathrm{~m}-0.5 \mathrm{~m}$, and more than 0.5 $\mathrm{m}$; and Keuper shales and limestones) for which a total of 426 individual classifications were made. Results of such plots have been previously published in Huisman and Hack (2002).

The parameter $\left(\mathrm{WE}_{\text {initial }}-\mathrm{WE}_{\text {current }}\right)$ indeed increases with time, but at a decreasing rate; the increase is, however, more or less linear when plotted against the logarithm of time. An example of the change in WE plotted against a logarithmic time scale is given in Figure 3 for Keuper shales. With the aid of bootstrapping techniques, it is also possible to calculate the percentiles that determine reliability intervals resulting from the possible spread of WE values within one single classification class (Huisman and Hack, 2002). Although these plots show generally good relationships, there is still some spread in the data. In Figure 3 for example, the individual data points deviate somewhat from the regression fit. This is in part the result of the influence of the internal, external, and geotechnic weathering conditions that form the subject of this article.

A general empiric relation to describe the intensity of weathering as suggested by Colman (1981) is (Eq. 1):

$$
\frac{P}{P_{0}}=a+b \log (1+t)
$$

In Eq. 1, the ratio $P / P_{0}$ represents a decrease of some property $P$ with respect to the fresh state $P_{0}$, and $a$ and $b$ are constants. In terms of weathering, $P / P_{0}$ is exactly what WE stands for (Hack, 1998), and Eq. 1 can be converted to define a weathering rate as (Eq. 2): 


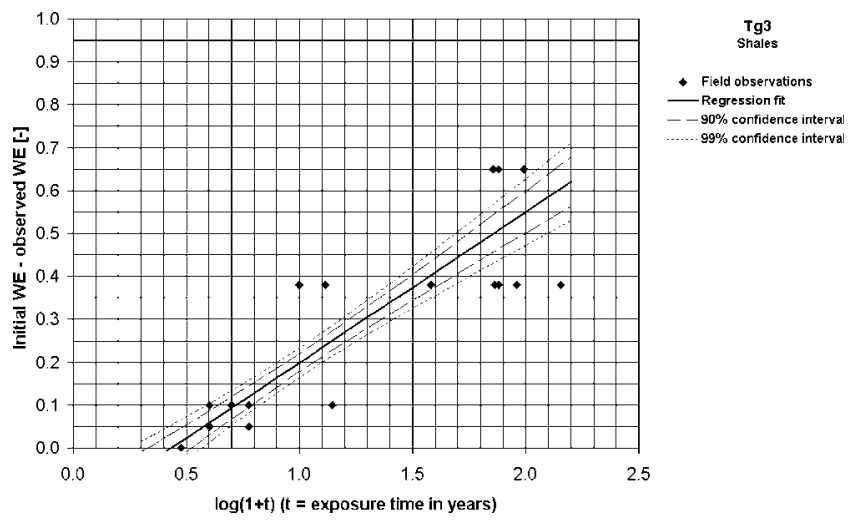

Figure 3. Decrease in WE plotted against exposure time for Keuper shales (field observations, regression fit, and confidence intervals).

$$
\begin{aligned}
\mathrm{WE}(t) & =\mathrm{WE}_{\text {initial }}-R_{\mathrm{WE}} \log (1+t) \\
\Rightarrow R_{\mathrm{WE}} & =\frac{\mathrm{WE}_{\text {initial }}-\mathrm{WE}(t)}{\log (1+t)}
\end{aligned}
$$

where $R_{\mathrm{WE}}$ is the weathering rate (1/log [year]), $\mathrm{WE}_{\text {initial }}$ is $\mathrm{WE}$ at time of excavation, $\mathrm{WE}(t)$ is $\mathrm{WE}$ after time $t$, and $t$ is the exposure time of slope in years. This agrees with the observation that $\left(\mathrm{WE}_{\text {initial }}-\mathrm{WE}_{\text {current }}\right)$ shows a linear relation with logarithmic time. Weathering rates according to Eq. 2 have been calculated for all individual data points. Average, maximum, and minimum rates per unit are given in Table 4. Obviously, the weaker formations (i.e., siltstones, shales) have the highest average weathering rates, up to about five times as high as the limestones of the Upper Muschelkalk and Keuper.

\section{PARAMETERS CONTROLLING WEATHERING}

All units show a significant variation in the individual rates, with standard errors that are about 50 percent of the averages (Table 4), which exceeds inevitable but acceptable scatter. To some extent this results from the fact that in a classification, WE is only determined as a discrete value out of the five possible (see Table 3), whereas in reality it is a normally distributed stochastic variable (Hack, 1998). The variation is likely to have a physical background as well, linked to the influence of the internal, external, and geotechnic weathering conditions. This influence will be most important in the units that have a high susceptibility to weathering: the Middle Muschelkalk siltstones and Keuper shales.

One particular geotechnic condition that has been investigated before and is thought to be of high importance is the influence of the slope orientation on weathering processes occurring in that slope. On a material scale, this has been investigated by analyzing the decay of gravestone inscriptions (e.g., Williams and Robinson, 2000) or rock tablets (e.g., Matsukura and Hirose, 1999). On

\begin{tabular}{|c|c|c|c|}
\hline \multirow{3}{*}{$\begin{array}{l}\text { Formation (Code) } \\
\text { Middle Muschelkalk } \\
\text { (Tg22) }\end{array}$} & \multirow{2}{*}{$\begin{array}{r}\text { Unit } \\
\text { Siltstones }\end{array}$} & \multicolumn{2}{|c|}{$\begin{array}{l}\text { Weathering Rates } \\
(1 / \log \text { [year] })\end{array}$} \\
\hline & & Average & 0.325 \\
\hline & & Minimum & 0.064 \\
\hline & & Maximum & 0.692 \\
\hline & & Standard error & 0.161 \\
\hline & Gypsum & Average & 0.133 \\
\hline & & Minimum & 0.000 \\
\hline & & Maximum & 0.244 \\
\hline & & Standard error & 0.070 \\
\hline \multirow{12}{*}{$\begin{array}{l}\text { Upper Muschelkalk } \\
\text { (Tg23) }\end{array}$} & Bedding spacing & Average & 0.052 \\
\hline & $<0.10 \mathrm{~m}$ & Minimum & 0.023 \\
\hline & & Maximum & 0.153 \\
\hline & & Standard error & 0.030 \\
\hline & Bedding spacing & Average & 0.042 \\
\hline & $0.10 \mathrm{~m}-0.50 \mathrm{~m}$ & Minimum & 0.019 \\
\hline & & Maximum & 0.105 \\
\hline & & Standard error & 0.019 \\
\hline & Bedding spacing & Average & 0.042 \\
\hline & $>0.50 \mathrm{~m}$ & Minimum & 0.019 \\
\hline & & Maximum & 0.129 \\
\hline & & Standard error & 0.024 \\
\hline \multirow[t]{8}{*}{ Keuper (Tg3) } & Shales & Average & 0.169 \\
\hline & & Minimum & 0.000 \\
\hline & & Maximum & 0.380 \\
\hline & & Standard error & 0.108 \\
\hline & Limestones & Average & 0.067 \\
\hline & & Minimum & 0.000 \\
\hline & & Maximum & 0.166 \\
\hline & & Standard error & 0.024 \\
\hline
\end{tabular}

Table 4. Weathering rates for the different geotechnical units.

a rock mass scale, Nicholson (2001) tried to extend such research to actual slopes; both types of study suggested that a delicate balance exists between exposure to sunlight, wind, and rain. Using the amount of data available, we have empirically approached this problem. With the weathering rates as previously defined, an analysis was made of the weathering rate for slopes in different orientations. The raw data already indicate a relation between slope orientation and observed weathering rates. To smooth out variations caused by singular observations, a bootstrap approach was followed. Latin Hypercube simulations were made for every data point, varying the WE coefficient, slope aspect, and exposure time. In these simulations, WE was taken from a normal distribution with averages according to Table 3 and standard errors after Hack (1998). The slope aspect was also taken from a normal distribution with averages equal to the recorded value and a standard error of $5^{\circ}$ (Hack, 1998). The exposure time is simulated from a triangular distribution, with the most likely value equal to the estimated exposure time, and maximum and minimum at \pm 10 percent of this estimate. Huisman and Hack (2002) used a similar methodology. Bootstrapping in general is described at length by Efron and Tibshirani (1998) and Chernick (1999). 
Figure 4 gives the bootstrapping results for the seven units that were described before, for 2,000 Latin Hypercube replications per data point. The graphs show the weathering rates as defined by Eq. 2 as the distance from the origin. The direction indicates the slope aspect. It should be noted that in these figures, the percentages do not indicate confidence levels but the fractions of the simulated data. A comparison between observed rates and rates predicted on the basis of the simulations show that the 50th percentiles give the best estimate when used to make such predictions.

The graphs in Figure 4 indicate that the slope aspect does indeed influence the weathering rate, with the marked asymmetry of the bootstrap percentiles that results of different weathering rates $(=$ distance from origin) in different slope orientations (= direction). For example, the weathering rates for Keuper shales are approximately twice as large in southeast-facing slopes than in northwest-facing slopes. This influence of slope aspect in itself is not surprising; authors such as Williams and Robinson (2000) have already shown that the orientation of headstones on graveyards plays a role in weathering. The climate seems to be a governing factor in this relationship between weathering and orientation. It was for example found by Cantón and others (2001) that exposure of gypsiferous mudstones to cyclic wetting and drying determines the rate and extent of weathering; indeed, even seasonal variations in precipitation can be directly linked to degradation of weak rock masses (Reguiés et al., 1995). It is, therefore, necessary to relate the graphs for the different units to the prevailing climate in the study area before an interpretation of the results can be made. This task is facilitated by highly detailed climate data available through Xarxes METeorològiques (XMET), a network of automated meteorologic stations distributed over Catalunya. All stations deliver their data to the central server of the Servei Meteorològic in Barcelona. In 2003, a total of 58 stations were active, giving access to very detailed climate data. Two XMET stations are located in the Falset study area: one near the town of Falset itself, and the other near Botarell, on either side of the El Camp mountain front.

With the available data for 2003, an analysis was made of the prevailing wind direction during rainfall events, as well as the wind velocity during those events. Figure 5 gives the distribution of wind directions for the Falset station, for precipitation classes as defined in Table 5.

Although the overall prevailing wind direction through the year is from the northwest, this changes to the southeast when rainfall increases. As Figure 6 shows, the average wind velocity for the winds from the southeast increases with increasing precipitation rate. In other words, when it rains the wind tends to blow from the southeast with an increasing velocity with increasing precipitation.
Based on the results of Figures 5 and 6, the graphs in Figure 4 reveal the influences of the climate conditions on the weathering processes in the various rocks. It is clear that the weathering rates found for the Keuper shales and dolomites (Figure $4 \mathrm{a}$ and b), which are usually interbedded with shaley material, correspond as far as their preferential orientation is concerned to the wind directions during precipitation events. In slopes facing the wind during such events, wetting and drying cycles and associated swelling and shrinking will be most intense and pronounced. This will lead to higher physical weathering rates in these slopes, corresponding to results found by Cantón and others (2001). An important additional factor to note is the presence of small amounts of swelling clays in the Keuper shales (based on x-ray fluorescence/x-ray diffraction tests that are approximately 4 percent by volume, with a total clay amount of 25 percent to 30 percent). Kühnel (2002) described the importance even of small amounts of swelling clays, and cyclic swelling and shrinking is in such materials a dominant degradation process (e.g., Pejon and $\mathrm{Zu}-$ quette, 2002).

In contrast, the gypsum parts of the Middle Muschelkalk tend to weather fastest in slopes facing toward the north, relatively sheltered from the wind during rainfall (Figure 4c). The Middle Muschelkalk siltstones, which also contain some gypsum (approximately 10 percent by volume), show highest weathering rates in northeast- to east-facing slopes (Figure 4d), which is close to the preferential wind direction during rainfall. The similarity to the precipitation data is, however, less than for the Keuper shales. It is believed that water retention plays an important role here, especially for the gypsum unit itself. In slopes sheltered from the wind, drying out of the material directly after rainfall is slower and, in soluble materials such as gypsum, this may give rise to faster (chemical) weathering. In the Middle Muschelkalk siltstones, this effect will still exist because of the gypsum present as cement between the grains but, as Figure 4 suggests, the physical weathering by wetting and drying of the clays present in the material (as in the Keuper shales, 25 percent to 30 percent by volume) is dominant, leading to highest weathering rates in slopes that face more toward the wind during rainfall.

The limestone units of the Upper Muschelkalk have a low susceptibility to weathering and consequently show the smallest weathering rates. Preferential directions are not as obvious as in the weaker rocks, especially when looking at the 50th percentiles (Figure 4e, f, and g). In the thinly bedded unit with bedding spacings less than $10 \mathrm{~cm}$, the influence of slope aspect seems to be most pronounced, again indicating highest weathering rates in east- to southeast-facing slopes. This is explained by the regular occurrence of shales and marls interbedded with the limestones in this unit. 
Predicting Rock Mass Decay in Engineering Lifetimes



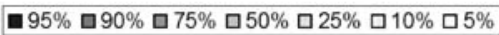
a. (Keuper shales)

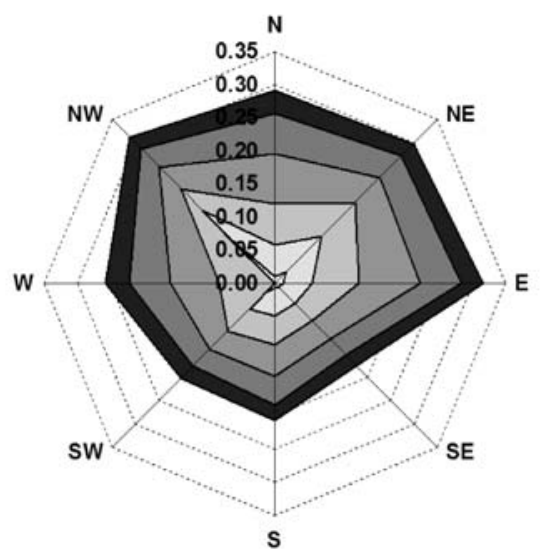

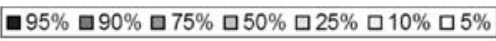
c. (Middle Muschelkalk gypsum)

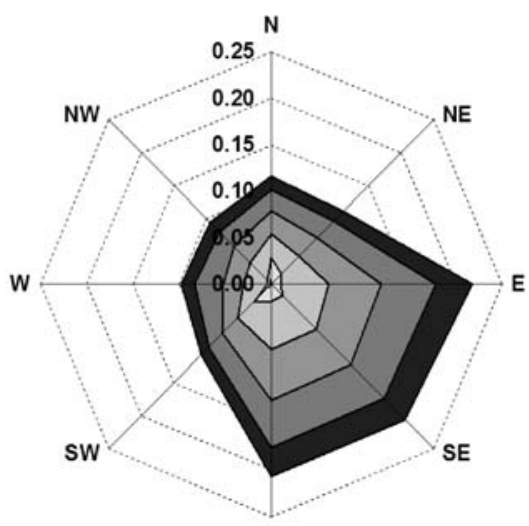

s

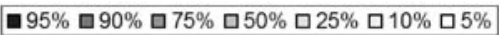

b. (Keuper limestones)



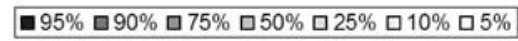

d. (Middle Muschelkalk siltstones)

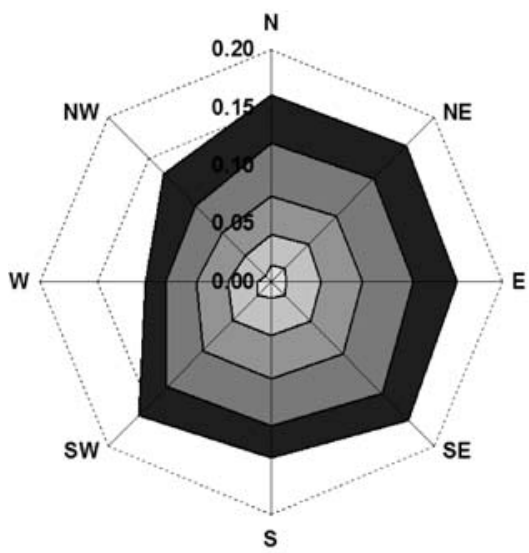

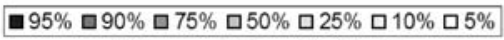

e. (Upper Muschelkalk, $\mathrm{BS}<0.10 \mathrm{~m})$

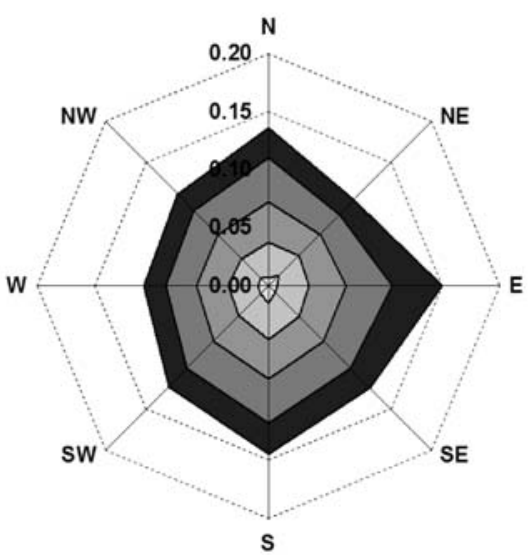



f. (Upper Muschelkalk, $0.10<\mathrm{BS}<0.50 \mathrm{~m}$ )

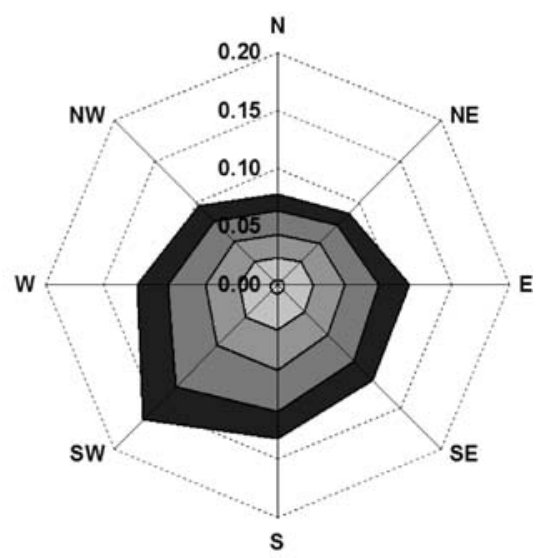



g. (Upper Muschelkalk, $\mathrm{BS}>0.50 \mathrm{~m})$

Figure 4. Weathering rates for the different units after 2,000 Latin Hypercube simulations. Percentages indicate the fraction of the simulated data falling within the indicated area. 
Distribution of wind directions, no precipitation $(96.4 \%$ of total) XMET station Falset (data for 2003)

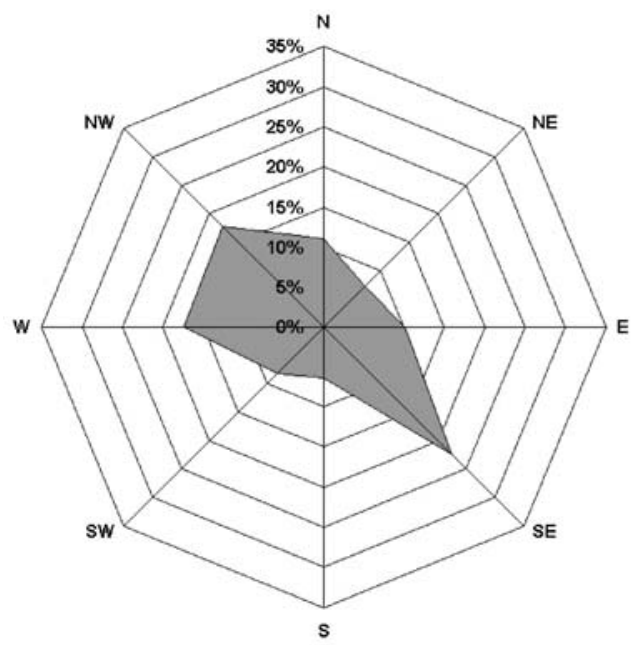

a.

Distribution of wind directions, light precipitation (1.7\% of total) XMET station Falset (data for 2003)

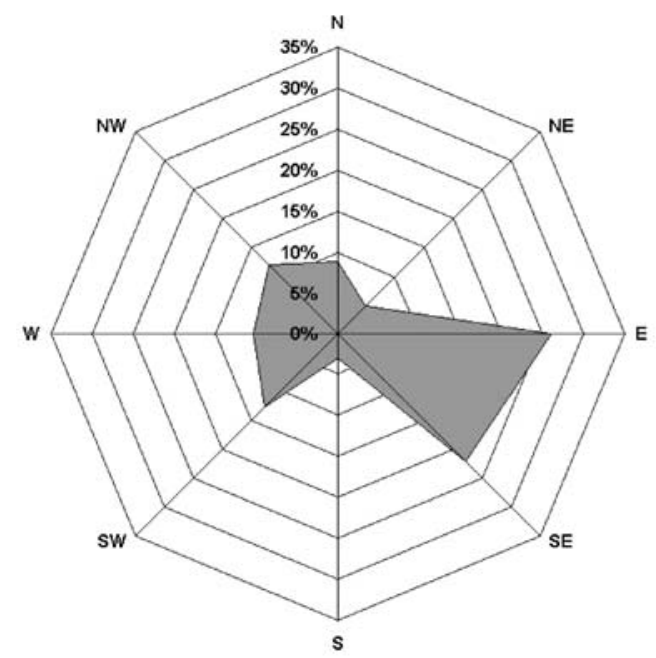

c.
Distribution of wind directions, drizzle (1.9\% of total) XMET station Falset (data for 2003)

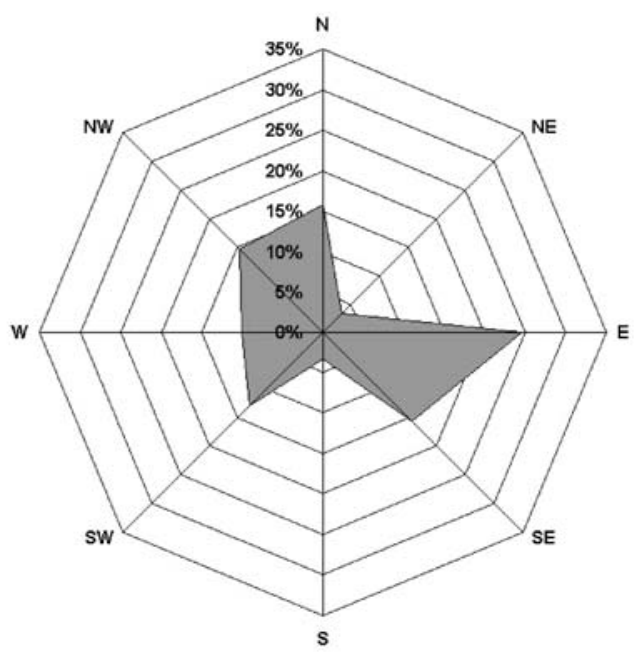

b.

Distribution of wind directions, moderate precipitation ( $0.6 \%$ of total) XMET station Falset (data for 2003)



d.

Figure 5. Wind directions as fraction of all data for four precipitation intensity classes (data for the Falset XMET station, 2003).

\section{SLOPE STABILITY PREDICTION}

In the SSPC system, the WE parameter, which is predicted on the basis of the bootstrap percentiles for apparent weathering-intensity rates for the different engineering geologic units, can be directly incorporated in its stability models. These stability models are extensively described by Hack (1998) and Hack and others (2003). Because a prediction of the weathering-intensity rate results in an expression for WE as a function of time, this leads to time-dependent functions for orientationdependent and -independent stability for the respective bootstrap percentiles. By additionally incorporating a time-dependent slope angle based on an average slopeangle decrease, the effect of erosion can also be assessed.

Because such slope-stability prediction may include an extrapolation of the data set (on which it is based) into the future, the results should then be treated as such with due consideration. The 50 percent bootstrap percentiles for weathering rates, when converted to weathering in- 
Table 5. Definition of precipitation classes according to Selby (1993).

\begin{tabular}{lc}
\hline \hline Precipitation Intensity & Precipitation (mm/hour) \\
\hline Drizzle & $0.25-1.02$ \\
Light rain & $1.02-3.81$ \\
Moderate rain & $3.81-15.24$ \\
Heavy rain & $15.24-40.64$ \\
Very heavy rain & $40.64-101.60$ \\
Torrential rain & $>101.60$ \\
\hline
\end{tabular}

tensities, have the best agreement on average with the actual observations. Therefore, the 50th percentile lines are believed to give the most reliable prediction of weathering intensities and resulting slope stability changes in the future (i.e., qualitative, if not quantitative).

\section{CONCLUSIONS}

An analysis of rock mass weathering in road cuts in the study area around the Spanish town Falset shows that significant weakening of the rock masses can occur well within anticipated engineering lifetimes of those cuts. As this may have serious implications for the slope stability, quantification of this process is very important for the design of road cuts, especially when excavating formations that have a high susceptibility to weathering.

To quantify the amount and rate of decay, classifications made using the SSPC system were analyzed and the resulting weathering rates were related to the orientation of the slopes. Other factors, such as local hydrologic conditions, temperature fluctuations, and vegetation cover, will also influence weathering in slopes. On a site scale, these other factors may even obscure the effect of slope orientation and the local climate. This has previously been suggested by the results of Nicholson (2001), who found it difficult to directly relate the results of weathering experiments in laboratory conditions to observations in real-life slopes because of this. The large amount of data available for the study area combined with bootstrapping does show regional trends in weathering rates. These trends may not directly apply to a specific location, but they are still considered useful for prediction purposes. For the study area around Falset, it can be concluded that in shales, marls, and similar materials containing clays (especially swelling clays), weathering rates are highest in slopes facing the prevailing winds during rainfall because of cyclic wetting and drying. The same holds true for more resistant materials such as limestones, which are interbedded with weak materials as shales and marls. In soluble materials such as the gypsum unit investigated here, water retention in slopes sheltered from the winds facilitates chemical weathering, and it is in these lee-side slopes that highest weathering rates are found. This shows the importance of assessing microclimate conditions when predicting rock

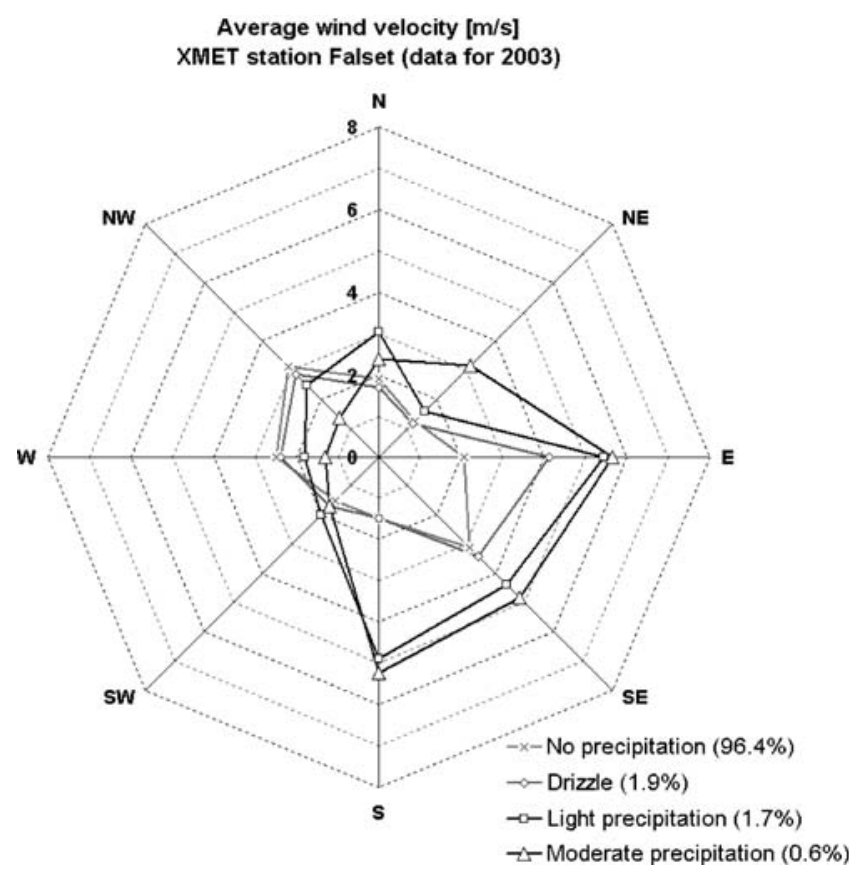

Figure 6. Average wind velocities for four precipitation classes (data for the Falset XMET station, 2003).

mass decay because they are closely linked to the observed weathering rates.

The weathering rates as found by the approach followed in this study can be used to predict degrees of weathering (quantified using the WE coefficient) as a function of time in the future. With this, the decreasing slope stability in time can also be predicted using the SSPC system. Although the quantitative results of this study may not be extrapolated to other areas with different climatic conditions, different rock units, etc., the qualitative idea remains: insight in the interaction between the weathering conditions and the rock units exposed in a cut can help prevent slope instability developing because of rock mass decay.

\section{REFERENCES}

Bland, W. AND Rolls, D., 1998, Weathering-An Introduction to the Scientific Principles: Arnold Publishers, London, 288 p.

BS5930, 1981, Code of Practice for Site Investigations: British Standards Institution, London.

BS5930, 1999, Code of Practice for Site Investigations: British Standards Institution, London.

Cantón, Y.; Solé-Benet, A.; Queralt, I.; And Pini, R., 2001, Weathering of a gypsum-calcareous mudstone under semi-arid environment at Tabernas, SE Spain: laboratory and field-based experimental approaches: Catena, Vol. 44, pp. 111-132.

Chernick, M. R., 1999, Bootstrap Methods: A Practitioner's Guide: Wiley, New York, 288 p.

Colman, S. M., 1981, Rock-weathering rates as functions of time: Quaternary Research, Vol. 15, pp. 250-264.

DeARman, W. R., 1995, Description and classification of weathered rocks for engineering purposes: the background to the BS5930: 
1981 proposals: Quarterly Journal Engineering Geology, Vol. 28 , pp. 267-276.

DE Jong, G., 2003, The Quantification of Weathering and Degradation in Engineering Time: Unpublished M.Sc. Thesis, Delft University of Technology, Delft, The Netherlands.

Dick, J. C. AND Shakoor, A., 1995, Characterizing durability of mudrocks for slope stability purposes, In Haneberg, W. C. and Anderson, S. A. (Editors), Clay and Shale Slope InstabilityReviews in Engineering Geology, Vol. X: The Geological Society of America, Boulder, CO, pp. 121-130.

Efron, B. And Tibshirani, R., 1998, An Introduction to the Bootstrap. Chapman \& Hall/CRC Press, Boca Raton, FL, 436 p.

Fookes, P. G.; Gourley, C. S.; And Ohikere, C., 1988, Rock weathering in engineering time: Quarterly Journal Engineering Geology, Vol. 21, pp. 33-57.

HaCK, H. R. G. K. AND Price, D. G., 1997, Quantification of weathering. In Marinos, P. G.; Koukis, G. C.; Tsiambaos, G. C.; and Stournaras, G. C. (Editors), Proceedings Engineering Geology and the Environment, Athens: Balkema, Rotterdam, The Netherlands, pp. 145-150.

HАCK, H. R. G. K., 1998, Slope Stability Probability Classification, 2nd ed.: Ph.D. Thesis, ITC, Delft, The Netherlands.

Hack H. R. G. K. And Huisman, M., 2002, Estimating the intact rock strength of a rock mass by simple means. In van Rooy, J. L. and Jermy, C. A. (Editors), Engineering Geology for Developing Countries-Proceedings of 9th Congress of the International Association for Engineering Geology and the Environment: South African Institute of Engineering Geologists (SAIEG), Durban, South Africa, pp. 1971-1977.

Hack, H. R. G. K.; Price, D. G.; and Rengers, N., 2003, A new approach to rock slope stability - a probability classification (SSPC): Bulletin Engineering Geology Environment, Vol. 62, pp. 167-184 and erratum p. 185.

Huisman, M., 2001, Case: Reconstruction of the N420 road in the province of Tarragona, Spain: Ingeokring Newsletter, No. 9 , pp. 17-25.

Huisman, M. AND Hack, H. R. G. K., 2002, Quantifying slope stability decrease in engineering lifetimes using bootstrap percentiles. In Dinis da Gama, C. and Ribeiro e Sousa, L. (Editors), Proceedings Eurock 2002-I. S. R. M. International Symposium on Rock Engineering for Mountainous Regions, Madeira, Portugal: Publ. Sociedade Portuguesa de Geotecnia, Portugal, pp. 197-204.

IGME (Instituto Geologico y Minero de España), Mapa geologico de España (1:50.000), Segunda serie, Primera edición. Map sheets 444/32-17 (Flix; 1979), 445/33-17 (Cornudella; 1978), 471/32-18 (Mora de Ebro; 1981), 472/33-18 (Reus; 1980). IGME, Madrid.

INKPEN, R. J. AND JACKSON, J., 2000, Contrasting weathering rates in coastal, urban and rural areas in southern Britain: preliminary investigations using gravestones: Earth Surface Processes Landforms, Vol. 25, pp. 229-238.

IRFAN, T. Y. AND DEARMAN, W. R., 1978, Engineering petrography of a weathered granite: Quarterly Journal Engineering Geology, Vol. 11, pp. 233-244.

Krömmelbein, K. (Editor), 1976, Brinkmanns Abriß der Geologie, Band II: Historische Geologie (10./11. Auflage): Ferdinand Enke Verlag, Stuttgart.

Kühnel, R. A.; van der GaAst, S. J.; Brych, J.; LaAn, G. J.; And KuLNIG, H., 1994, The role of clay minerals in durability of rocks: observations on basaltic rocks: Applied Clay Science, Vol. 9, pp. 225-237.

KüHNEL, R. A., 2002, Driving forces of rock degradation. In Galán, E and Zezza, F. (Editors), Proceedings Protection and Conservation of the Cultural Heritage of the Mediterranean Cities, Sevilla, Spain: Balkema, Rotterdam, The Netherlands, pp. 11-17.

Laubscher, D. H., 1990, A geomechanics classification system for the rating of rock mass in mine design: Journal South African Institute Mining Metallurgy, October, pp. 257-272.

LóPEZ-Gómez, J.; Mas, R.; AND ARChe, A., 1993, The evolution of the Middle Triassic (Muschelkalk) carbonate ramp in the SE Iberian ranges, eastern Spain: sequence stratigraphy, dolomitization processes and dynamic controls: Sedimentary Geology, Vol. 87, pp. 165-193.

Martin, R. P., 1986, Use of index tests for engineering assessment of weathered rocks. In Proceedings of the 5th International IAEG Congress, Buenos Aires 1986: International Association of Engineering Geology and the Environment (IAEG), Balkema, Rotterdam, The Netherlands, pp. 433-450.

Masana, E., 1994, Neotectonic features of the Catalan coastal ranges, northeastern Spain: Acta Geologica Hispanica, Vol. 29, No. 2-4, pp. 107-121.

Matsukura, Y. AND HiRose, T., 1999, Five year measurements of rock tablet weathering on a forested hillslope in a humid temperate region: Engineering Geology, Vol. 55, pp. 69-76.

Morad, S.; Al-Aasm, I. S.; LongstafF, F. J.; Marfil, R.; de Ros, L. F.; Johansen, H.; And Marzo, M., 1995, Diagenesis of a mixed siliclastic/evaporitic sequence of the Middle Muschelkalk (Middle Triassic), the Catalan coastal range, NE Spain: Sedimentology, Vol. 42, pp. 749-768.

Nicholson, D. T., 2001, Deterioration of Excavated Rockslopes: Mechanisms, Morphology and Assessment: Ph.D. Thesis, University of Leeds, Leeds, UK.

Pejon, O. J. And Zuquette, L. V., 2002, Analysis of cyclic swelling of mudrocks: Engineering Geology, Vol. 67, pp. 97-108.

Price, D. G., 1993, A suggested method for the classification of rock mass weathering by a ratings system: Quarterly Journal Engineering Geology, Vol. 26, pp. 69-76.

PRICE, D. G., 1995, Weathering and weathering processes: Quarterly Journal Engineering Geology, Vol. 28, pp. 243-252.

RegüÉs, D.; PARDinI, G.; AND Gallart, F., 1995, Regolith behaviour and physical weathering of clayey mudrock as dependant on seasonal weather conditions in a badland area at Vallcebre, Eastern Pyrenees: Catena, Vol. 25, pp. 199-212.

Ruxton, B. P., 1968, Rates of weathering of Quaternary volcanic ash in north-east Papua: Journal Geology, Vol. 76, pp. 518-527.

Selby, M. J., 1993, Hillslope Materials and Processes, 2nd ed.: Oxford University Press, Oxford, UK, 451 p.

SHAKOOR, A., 1995, Slope stability considerations in differentially weathered mudrocks: In Haneberg, W. C. and Anderson, S. A. (Editors), Clay and Shale Slope Instability: Reviews in Engineering Geology, Vol. X: The Geological Society of America, Boulder, CO, pp. 131-138.

Trudgill, S. T.; Viles, H. A.; InkPen, R. J.; Moses, C.; Gosling, W.; Yates, T.; Collier, P.; Smith, D. I.; And Cooke, R. U., 2001, Twenty-year weathering remeasurements at St. Paul's Cathedral, London: Earth Surface Processes Landforms, Vol. 26, pp. 11291142.

Vecsei, A., 1998, A sandy tidal coast in the uppermost Muschelkalk and the origin of the Muschelkalk/Keuper boundary in the southwestern Germanic basin: Geologischer Rundschau, Vol. 86, pp. 835-851.

Vecsei, A. And Mandau, T., 2002, Redbeds from the Middle Muschelkalk (Middle Triassic) of the SW Germanic Basin: arid environments from Pangea's interior: International Journal Earth Sciences (Geologischer Rundschau), Vol. 91, pp. 111-122.

White, A. F. And Brantley, S. L., 2003, The effect of time on the weathering of silicate minerals: why do weathering rates differ in the laboratory and field? Chemical Geology, Vol. 202, pp. 479506.

Williams, R. B. G. And Robinson, D. A., 2000, Effects of aspect on weathering: anomalous behaviour of sandstone gravestones in 
south east England: Earth Surface Processes Landforms, Vol. 25, pp. 135-144.

WinKLER, E. M., 1997, Stone in Architecture: Properties and Durability, 3rd ed.: Springer-Verlag, New York.

\section{APPENDIX: DATA SIMULATION AND BOOTSTRAPPING}

The data-based simulation method for statistic inference described in this article is the mathematic equivalent to pulling oneself up by one's bootstraps (Efron and Tibshirani, 1998). Starting from a limited amount of observed data, a larger set of hypothetical, but still realistic, data are generated. Based on the distribution of this simulated data, statistic properties of the true data can be assessed with, in many cases, a much greater reliability than would be possible on the basis of the true data alone. This reliability of the results largely depends on the validity of the assumptions that are applied in the data simulation, and these should be made with care.

Bootstrapping generates a large amount of imaginary, yet realistic, data from a limited set of samples, enabling us to quantify statistic parameters that can only be determined with difficulty, or not at all, from the original samples (Efron and Tibshirani, 1998).

In Figure 7, the general line of bootstrapping is explained. In real life, observations that compose a data set $x$ result from the (unknown) probability distribution(s) $P$ of the stochastic variable(s) that compose $x$. In a threesample problem, a data "point" $x_{i}$ is an observation consisting of three variables, in a general form $x_{i}=(a, b, c) . \hat{\theta}$ is a statistical variable derived from the dataset $x$ and, thus, also depends on the probability model that forms the basis for $x$.

The bootstrap model of reality is in itself rather similar, the crux being the estimation of the probability model. Based on that estimated probability model $\hat{P}$, a hypothetical or simulated data set $x^{*}$ is created, consisting of data points $x_{i}^{*}$ that each consist of estimates for the composing stochastic variables (e.g., a simulated aspect, exposure time, and weathering degree). The trick is that as many data points can be simulated as desired and, therefore, that we can find a larger simulated data set $\hat{\theta}^{*}$ than possible for the "real" data set $\hat{\theta}$.

To apply the bootstrap method to an analysis such as that we are dealing with here, probability distributions have to be assigned to some or all of the input variables. In this study, three parameters are treated as stochastic

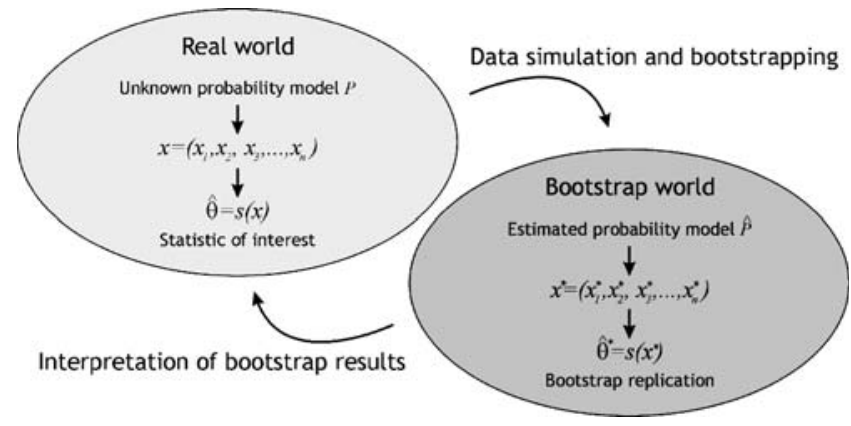

Figure 7. Bootstrap methodology (after Efron and Tibshirani, 1998).

variables: the recorded $W E$, exposure time, and slope aspect. Various alternatives exist for assigning probability distributions such as a normal distribution (quantified with mean and standard deviation), a block distribution (quantified with upper and lower boundaries), and a triangular distribution (quantified with lower, most likely, and upper values). The normal distribution and similar types do not have a fixed upper or lower boundary; in theory, any value is possible (albeit with a very small probability for extremely low or high values), whereas the block and triangular distributions do have a fixed upper and lower limit.

A bootstrap analysis starts with a data simulation process (e.g., Monte Carlo or, as in this case, Latin Hypercube sampling), generating an imaginary data set. From this data set, the set of resulting variables such as the weathering-intensity rate is calculated. The bootstrap percentiles such as those used in this study are the contours that indicate the fractions of this resulting variable and are effective methods to determine reliability intervals (e.g., Chernick, 1999). Following the notation by Efron and Tibshirani (1998) and Figure 7, the percentiles are derived from a set of $B$ bootstrap replications that make up $\hat{\theta}^{*}(B)$. This itself is of course derived from $B$-simulated data points $x^{* 1}, x^{* 2}, x^{* 3}, \ldots$, $x^{* B}$. If $\hat{\theta}_{B}^{*(\alpha)}$ is the $\alpha$-percentile $(0 \leq \alpha \leq 1)$, that is, the $\alpha^{*} B$ th value in the ordered vector $\hat{\theta}^{*}(B)$, then $\hat{\theta}_{B}^{*(\alpha)}$ gives the single-sided bootstrap percentile for $\alpha$, and the interval $\left[\hat{\theta}_{B}^{*(\alpha)}, \hat{\theta}_{B}^{*(1-\alpha)}\right]$ gives the two-sided bootstrap percentiles for $1-2 \alpha$. These single- and two-sided percentiles are the bootstrap estimates for the respective single- and two-sided confidence limits (Efron and Tibshirani, 1998). 